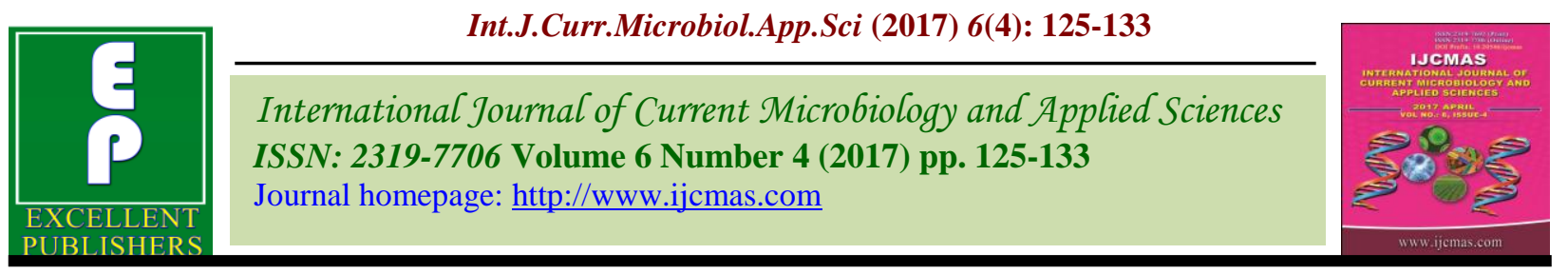

Original Research Article

https://doi.org/10.20546/ijcmas.2017.604.015

\title{
Microbiological Characteristic of Cinnamon Pseudopodzolic Soil (Planosol) at Using of Black Sea Deep-Water Sediments (Sapropels)
}

\author{
Tsveta H. Hristeva* and Radka P. Bozhinova \\ Department of Plant Protection and Agriculture, Tobacco and Tobacco Products \\ Institute, 4018 Plovdiv, Bulgaria \\ *Corresponding author
}

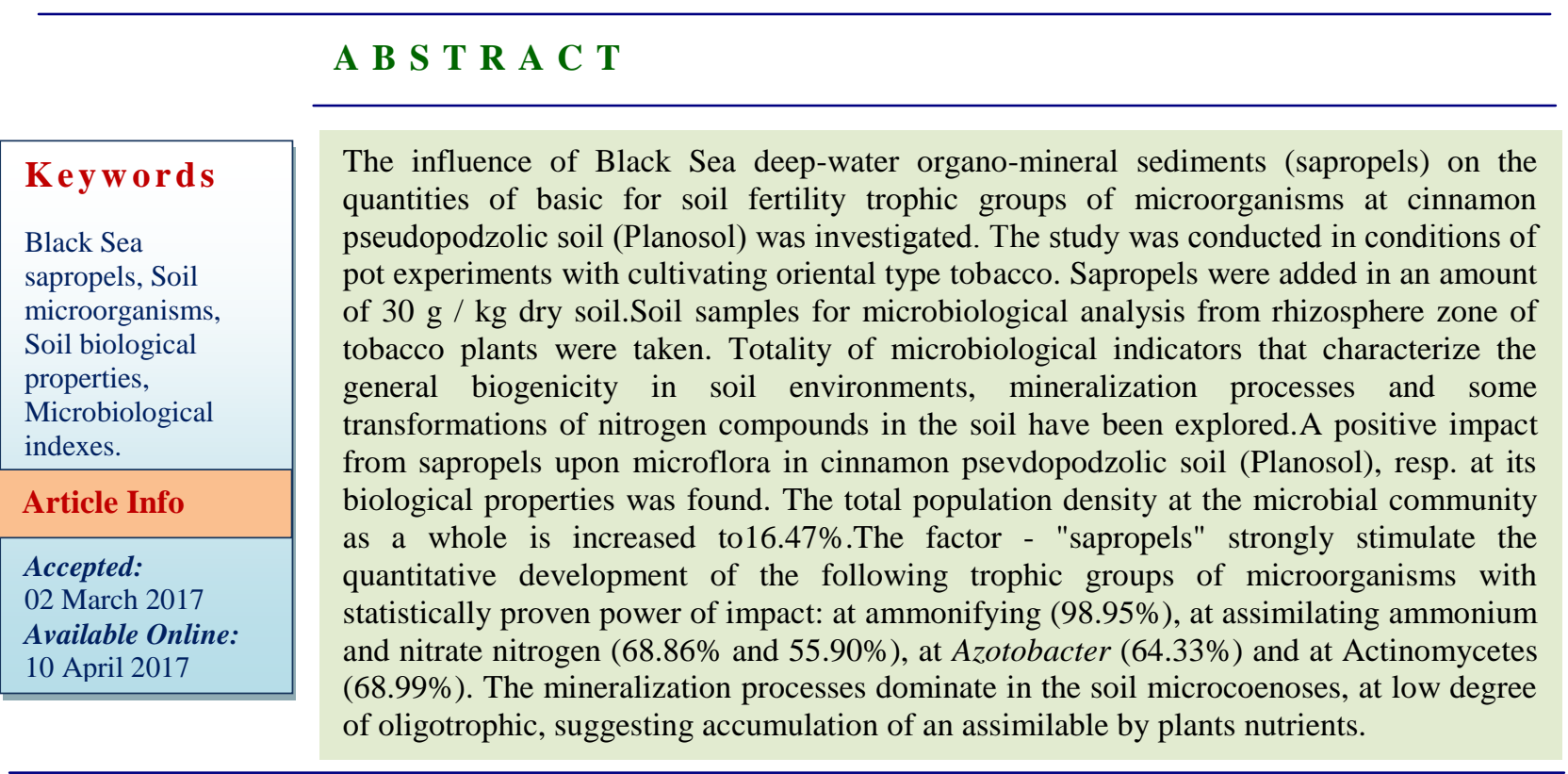

\section{Introduction}

A key factor for achieving sustainable management of agro-ecosystems is maintain and improve quality of soils, respectively their fertility (Lal, 2009). The content of humus and nutrients for the plants are indicators of soil fertility, but a leading role in the processes of its creation, maintaining and improving there are soil microorganisms. This role is determined by the fundamental activity that they doing in the substances circulation and primary transformation of organic matter flow (Kennedy et al., 2004; Dobrovolskaya et al., 2016). In the specific physicochemical properties of a soil are formed specific microbial communities, from whose quantitative and functional biodiversity depend intensity of the processes running in the soil (Doran and Zeiss, 2000; Brussard et al., 2007). Microbial communities are dynamic and rapidly adaptable to change. This enables for the impact regulation and management towards sustainability of agro ecosystems (Sparling 1997; Schutter and Dick, 2001; Larkin et al., 2006; Saison et al., 2006;Barrios, 2007; Dobrovolskaya et al., 2015). In this connection rise the demand the 
development and implementation of new technological decisions to include organic products of different origins for eco-friendly and sustainable agricultural production (Buyer et al., 2010; Fritz et al., 2012; Lukas S., 2013). Various organo-mineral sediments deposited in water bodies - sapropels are with high potential as an organic fertilizer (Baksiene, 2009; Emeis and Weissert, 2009). They are distinguished by various physical and chemical properties, different contents of organic and mineral substances, as well as specific microflora. The microbiological characteristics of some sapropels from Baltic lakes are characterized by high levels of aerobic heterotrophic bacteria and yeasts, and also the presence of fungi zoospores (Dzynban, 2002; Wurzbacher et al., 2010). Green non-sulfur bacteria (Chloroflexi), some archea (Srenarchaeota), facultative anaerobic or aerobic species of Micrococcus, Rhodococcus and Agrobacterium were contained in Mediterranean sediments (Coolen et al., 2002; Süss et al., 2004). An increased numbers in populations of microbial communities and microbial activity in different soil types after applying the lake sapropels as fertilizer was found (GrantinaLevina et al., 2014). Positive results were obtained from the use of deep-sea sediments from the bottom of the Black Sea as agriameliorants and bio-stimulators for plants in recent years (Velev et al., 1992; Terziev et al., 2007; Shnyukov et al., 2009; Nikolov and Shaban, 2011; Nikolov, 2011; 2014; Nikolov and Tringovska, 2014; Bozukov and Kochev, 2014). Their impact on soil microflora and direction of mineralization processes in the soil are insufficient explored. Stimulate the development of Nitrogen-Fixing tuberous bacteria in some legumes after used the Black Sea sapropels have been observed (Dimitrov and Sabev, 2005).

The aim of this study is to determine the impact of the deepwater Black Sea sapropels on the quantities of basic for soil fertility trophic groups of microorganisms at cinnamon pseudopodzolic soil (Planosol).

\section{Materials and Methods}

The study was conducted in conditions of potted experiments (capacity of $5 \mathrm{~kg}$ ), with cultivating oriental type tobacco. Cinnamon pseudopodzolic soil (Planosol), with strongly acidic soil reaction $(\mathrm{pH}-4.79)$ and low humus content $(1.97 \%)$ it was used (Bozhinova et al., 2015). Sapropels were added in an amount of $30 \mathrm{~g} / \mathrm{kg}$ dry soil, and the mixture was incubated for 2 months. Containers without sapropels for control it was used. Experience was enshrined in five reps.

Soil samples for microbiological analyses were taken from rhizosphere zone of tobacco plants, at a depth 0-20 cm, 60 days of planting tobacco. The phenological phase of the plants was "active growth". Average soil sample from the five reps was used for analyses. Microbiological analyses were performed by the method of Koch by plating of dilute soil suspensions in relevant for each group of microorganisms culture media, in four repetitions. The quantities of microorganisms were calculated as the most probable number of cells (MPN) per $g$ of absolutely dry soil (a.d.s.) at the confidence level 0.05 the following formula:

MPNcells $=\frac{\left(\bar{\chi} \pm t \sigma_{x}\right) \cdot \frac{K}{V}}{D_{m}}$

where: $\bar{Z}$ is the average number of colonies of all reps; $\mathrm{t}=2$ at $P_{0.95} ; \sigma_{\chi}$-mean square deviation; $\mathrm{K}$ - dilution from which has been made; $\mathrm{V}$ - the volume of the inoculum in $\mathrm{ml}$; $\mathrm{D}_{\mathrm{m}}$-amount of dry matter in $\mathrm{g}$ soil (Grudeva et al., 2006). 
The following microbiological indicators have been determined:

Number of: Autochthonous microorganisms on soil extract agar, for ten days were incubated; Oligotrophic microorganisms - on tenfold diluted soil extract agar, for ten days were incubated; Actinomycetes - on starchammonium agar, for seven days were incubated; Microscopic fungi - on Chapek agar, for seven days were incubated; Aerobic nitrogen-fixing bacteria of the genus Azotobacter - on Ashby agar, for seven days were incubated; Ammonifying microorganisms - on meat - peptone stock agar, for five days were incubated; Mineral nitrogen $\mathrm{NH}_{4}{ }^{+}$assimilating microorganisms on starch-ammonium agar, for seven days were incubated; Mineral nitrogen $\mathrm{NO}_{3}$ assimilating microorganisms - on ChapekDox agar, for seven days were incubated.

Structural microbiological indexes have been calculated: Oligotrophic index (OI) - ratio between Oligotrophic microorganisms and Autochthonous microorganisms; Mineralization-immobilization indexes ratios between assimilating mineral $\mathrm{NH}_{4}{ }^{+}-\mathrm{N}$ or mineral $\mathrm{NO}_{3}^{-}-\mathrm{N}$ microorganisms and Ammonifying microorganisms.

The data were subjected to a single-factor dispersion analysis. For each trophic group of microorganisms and for overall population density in microbial communities the effect ( $\eta \times 2)$ of factor "sapropels" and the level of statistical significance (p) according to the Fisher's test (F) have been identified. Statistical evaluation of the specific differences between variants for each trophic group of microorganisms, using the Student's test (t) has been determined (Plochinskiy, 1980).

The relative shares (\%) of each of trophic group microorganisms of overall population density in microbial communities were calculated.

\section{Results and Discussion}

The population surveyed by trophic groups of soil microorganisms can be conditionally divided into:

Microorganisms that characterize the general biogenicity in the soil environment and actively participate in the mineralization of organic matter - autochthonous, oligotrophic, soil fungi and actinomycetes

Microorganisms that perform some transformations of nitrogen compounds in the soil - nitrogen-fixing aerobic bacteria from the Azotobacter, ammonifying microorganisms, assimilating mineral forms of nitrogen microorganisms.

The results of this study indicated that the presence of sapropels in cinnamon pseudopodzolic soil (Planosol) suppresses the numerical growth of microorganisms of the physiological groups united at ecologicallytrophic group associated with general biological state in the soil environment and total mineralization processes, with the exception of soil actinomycetes (Table 1).

The registered reduction of the density at autochthonous microorganisms in without sapropeles soil was of the order of $93.48 \times 10^{6}$ $/ \mathrm{g}$ a. d. s., unproven statistical $\left(\eta \mathrm{x}^{2}=0.261\right.$; $\mathrm{F}_{\text {exp. }}=2.48<\mathrm{F}_{\text {tab.90\% }}=3.59$ ). Decrease in density at oligotrophic microorganisms was significantly more pronounced - $173.87 \times$ $10^{6} / \mathrm{g}$ a. d. s. The difference with the control was proven at a high confidence level ( $p$ $\leq 0.001)$.

The force of impact of factor $\left(\eta_{\mathrm{x}}{ }^{2}\right)$ was $87.04 \%\left(\mathrm{~F}_{\text {exp. }}=47.02>\mathrm{F}_{\text {tab.99\% }}=12.25\right)$. Reduce of the number with $62.67 \times 10^{3} / \mathrm{g}$ a. d. 
s. it was recorded and at microscopic fungi with the force of impact of sapropels $43.65 \%$. Changes at this group microorganisms did confirmed statistically $\left(\mathrm{F}_{\text {exp. }}=5.42>\mathrm{F}_{\text {tab.90\% }}=3.59\right)$. Strong stimulating effect on the group of actinomycetes was reported. Their population density has increased more than five times compared to the control, with $13.65 \times 10^{6} / \mathrm{g}$ a. d. s.The impact of the factor was $68.99 \%$, at a high level of confidence demonstrated ( $p$ $\leq 0.01 ; \mathrm{F}_{\text {exp. }}=15.57>\mathrm{F}_{\text {tab. } 99 \%}=12.25$ ).

Microorganisms of these trophic groups inhabit the soil micro-coenosis from the time of their occurrence (Alexander, 1991). The introduction of sapropels in the soil changes the conditions of life in environments. These changes, together with a relatively brief period of adaptation of microbial communities are the possible reasons for the reported lower density of autochthonous and oligotrophic microorganisms. Regulatory factor for their development is the incoming flow of nutrients. Autochthonous microorganisms are mesotrophic and they are relatively conservative indicator, while oligotrophic microorganisms are active and their population density is higher when the easily degradable organic compounds in the soil environment were depletion (Ishida and Kadota, 1981). Inputting of sapropels due to the specifics of their origin probably initially act as an inhibitor on quantitative development of these two groups microorganisms. According to Nikolov (2014) sapropels are extremely rich in organic carbon - $199.7 \mathrm{~g} / \mathrm{kg}$ and humus content $68.5 \mathrm{~g} / \mathrm{kg}$. On the other hand received data suggests that this effect was temporary. This is confirmed by low values of oligotrophic index which indicates that the balance between both trophic groups in the microbial communities was maintained (Table 3 ). The main reason for the reduced density of microscopic fungi that for up growth prefer acidic living environment (Domsh, 1983) was the amendment in the reaction of the soil. The soil reaction from acidic $(\mathrm{pH} 4.79)$ towards slightly alkaline ( $\mathrm{pH}$ 7.57) in conditions of this experiment has been changed (Bozhinova et al., 2015). Actinomycetes require neutral soil reaction, as well as a high content of nutrients, unlike microscopic fungi (Zenova et $a l ., 2001)$. The increase in their numbers explains with the change in the soil reaction and the rich flow by organic matter introduced with sapropels. Quantities of actinomycetes in the soil are indicator of its fertility and ecological cleanliness. Their number and activity increases in parallel with increasing the organic matter in whose mineralization participate.

Indicators for the content, availability and the degree of destruction of the organic compounds in the soil are the quantities of autochthonous and oligotrophic microorganisms. Microscopic fungi together with actinomycetes due to their rich enzymatic systems actively decompose complex organic compounds resistant to the activity of most bacteria. The representatives of the four groups of microorganisms not only in mineralization processes, but also for the synthesis of humus in soil are involved (Atlas, 1981; Alexander, 1991). Increase in humus content of $1.97 \%$ to $2.38 \%$ at soil with sapropels of this experience was registered (Bozhinova et al., 2015).

Inputting into the soil of sapropels stimulates numerical development of all tested groups of microorganisms involved in the various processes of transformations of nitrogen compounds (Table 2).

More than four times the amount of Azotobacter chroococcum, the main representative of the group of nitrogen-fixing aerobic bacteria was increased. 
Table.1 Changes in the quantities at basic trophic groups of microorganisms in cinnamon pseudopodzolic soil/Planosol/ after introduce of sapropels

\begin{tabular}{|c|c|c|c|c|}
\hline \multirow[b]{2}{*}{$\begin{array}{c}\text { Microbiological } \\
\text { indicators - trophic } \\
\text { groups microorganisms }\end{array}$} & $\begin{array}{c}\text { Planosol - } \\
\text { withoutsapropels } \\
\text { /control/ }\end{array}$ & $\begin{array}{c}\text { Planosol } \\
+ \\
\text { sapropels }\end{array}$ & $\begin{array}{c}\text { Values of the } \\
\text { criterion of Student } \\
\left(t_{)}\right.\end{array}$ & \multirow{2}{*}{$\begin{array}{c}\text { Statistical } \\
\text { significance of } \\
\text { the differences } \\
( \pm D)\end{array}$} \\
\hline & $\begin{array}{l}\text { MPN cells } \pm \\
\text { confidence } \\
\text { interval } \\
\overline{\mathrm{x}} \pm_{\Delta} \mathrm{N}_{(\mathrm{p} \leq 0.95)}\end{array}$ & $\begin{array}{l}\text { MPN cells } \pm \\
\text { confidence } \\
\quad \text { interval } \\
\overline{\mathrm{x}} \pm_{\Delta} \mathrm{N}_{(\mathrm{p} \leq 0.95)}\end{array}$ & $\begin{array}{c}\text { significance levels } \\
\mathrm{t}_{\text {tab.5.0\% }}=1.943 \\
\mathrm{t}_{\text {tab. } 1.0 \%}=3.143 \\
\mathrm{t}_{\text {tab. } 0.1 \%}=5.208\end{array}$ & \\
\hline $\begin{array}{l}\text { Autochthonous } \\
\text { microorganisms }\end{array}$ & $\begin{array}{l}737.923 \times 10^{6} \pm \\
27165\end{array}$ & $\begin{array}{l}644.444 \times 10^{6} \\
\pm 25386\end{array}$ & $\mathrm{t}_{\mathrm{exp} .}=1.784<\mathrm{t}_{\text {tab. } 5.0 \%}$ & $-93.478 \times 10^{6 \text { n.s. }}$ \\
\hline \multicolumn{5}{|c|}{$\mathrm{GD}_{5 \%}=128.239 \times 10^{6} ; \mathrm{GD}_{1 \%}=194.272 \times 10^{6} ; \mathrm{GD}_{0.1 \%}=321.292 \times 10^{6}$} \\
\hline $\begin{array}{l}\text { Oligotrophic } \\
\text { microorganisms }\end{array}$ & $\begin{array}{l}453.502 \times 10^{6} \pm \\
21296\end{array}$ & $\begin{array}{l}279.630 \times 10^{6} \\
\pm 16722\end{array}$ & $\mathrm{t}_{\mathrm{exp}}=7.775>\mathrm{t}_{\mathrm{tab} .0 .1 \%}$ & $-173.87 \times 10^{6^{* * * *}}$ \\
\hline \multicolumn{5}{|c|}{$\mathrm{GD}_{5 \%}=54.722 \times 10^{6} ; \mathrm{GD}_{1 \%}=82.899 \times 10^{6} ; \mathrm{GD}_{0.1 \%}=133.260 \times 10^{6}$} \\
\hline Microscopic fungi & $\begin{array}{l}235.507 \times 10^{3} \\
\pm 242.645\end{array}$ & $\begin{array}{l}172.840 \times 10^{3} \\
\pm 207.870\end{array}$ & $\mathrm{t}_{\text {exp. }}=2.640>\mathrm{t}_{\mathrm{tab} .5 .0 \%}$ & $-62.668 \times 10^{3 *}$ \\
\hline \multicolumn{5}{|c|}{$\mathrm{GD}_{5 \%}=58.078 \times 10^{3} ; \mathrm{GD}_{1 \%}=87.983 \times 10^{3} ; \mathrm{GD}_{0.1 \%}=141.433 \times 10^{3}$} \\
\hline Actinomycetes & $\begin{array}{l}3.019 \times 10^{6} \\
\pm 868.810 \\
\end{array}$ & $\begin{array}{l}16.667 \times 10^{6} \\
\pm 2041.241 \\
\end{array}$ & $\mathrm{t}_{\mathrm{exp}}=4.474>\mathrm{t}_{\mathrm{tab} .1 .0 \%}$ & $+13.647 \times 10^{6 * *}$ \\
\hline
\end{tabular}

Table. 2 Changes in the quantities at basic trophic groups of microorganisms related to transformation of nitrogen compounds in cinnamon pseudopodzolic soil/Planosol/ after introduce of sapropels

\begin{tabular}{|c|c|c|c|c|}
\hline \multirow{2}{*}{$\begin{array}{l}\text { Microbiological indicators - } \\
\text { trophic groups } \\
\text { microorganisms }\end{array}$} & $\begin{array}{c}\text { Planosol - } \\
\text { withoutsapropels } \\
\text { /control/ }\end{array}$ & $\begin{array}{l}\text { Planosol } \\
+ \\
\text { sapropels }\end{array}$ & $\begin{array}{l}\text { Values of the } \\
\text { criterion of } \\
\text { Student } \\
\left(\mathrm{t}_{)}\right.\end{array}$ & \multirow[t]{2}{*}{$\begin{array}{l}\text { Statistical } \\
\text { significance of the } \\
\text { differences } \\
( \pm \mathrm{D})\end{array}$} \\
\hline & $\begin{array}{c}\text { MPN cells } \pm \\
\text { confidence interval } \\
\overline{\mathrm{x}} \pm_{\Delta} \mathrm{N}_{(\mathrm{p} \leq 0.95)}\end{array}$ & $\begin{array}{l}\text { MPN cells } \pm \\
\text { confidence } \\
\text { interval } \\
\overline{\mathrm{x}} \pm_{\Delta} \mathrm{N}_{(\mathrm{p} \leq 0.95)}\end{array}$ & $\begin{array}{c}\text { significance levels } \\
\mathrm{t}_{\text {tab. } 5.0 \%}=1.943 \\
\mathrm{t}_{\text {tab. } 1.0 \%}=3.143 \\
\mathrm{t}_{\text {tab. } 0.1 \%}=5.208\end{array}$ & \\
\hline $\begin{array}{l}\text { Aerobic nitrogen-fixing } \\
\text { bacteria Azotobacter }\end{array}$ & $\begin{array}{l}7.850 \times 10^{6} \\
\pm 1401\end{array}$ & $\begin{array}{l}34.568 \times 10^{6} \\
\pm 2940\end{array}$ & $\mathrm{t}_{\text {exp. }}=4.029>\mathrm{t}_{\mathrm{tab} .1 .0 \%}$ & $+26.718 \times 10^{6^{* *}}$ \\
\hline \multicolumn{5}{|c|}{$\mathrm{GD}_{5 \%}=16.228 \times 10^{6} ; \mathrm{GD}_{1 \%}=24.585 \times 10^{6} ; \mathrm{GD}_{0.1 \%}=35.520 \times 10^{6}$} \\
\hline $\begin{array}{l}\text { Ammonifyingmicroorganis } \\
\mathrm{ms}\end{array}$ & $\begin{array}{l}77.899 \times 10^{6} \\
\pm 4413\end{array}$ & $\begin{array}{l}301.852 \times 10^{6} \\
\pm 8688\end{array}$ & $t_{\text {exp. }}=29.19>t_{\text {tab. } .0 .1 \%}$ & $+223.95 \times 10^{6 * * *}$ \\
\hline \multicolumn{5}{|c|}{$\mathrm{GD}_{5 \%}=18.777 \times 10^{6} ; \mathrm{GD}_{1 \%}=28.446 \times 10^{6} ; \mathrm{GD}_{0.1 \%}=45.727 \times 10^{6}$} \\
\hline $\begin{array}{l}\text { Mineral nitrogen } \mathrm{NH}_{4}^{+} \\
\text {assimilating microorganisms }\end{array}$ & $\begin{array}{l}19.324 \times 10^{6} \\
\pm 2198\end{array}$ & $\begin{array}{l}121.605 \times 10^{6} \\
\pm 5514\end{array}$ & $\mathrm{t}_{\text {exp. }}=4.461>\mathrm{t}_{\text {tab. } 1.0 \%}$ & $+102.281 \times 10^{6^{* *}}$ \\
\hline \multicolumn{5}{|c|}{$\mathrm{GD}_{5 \%}=56.106 \times 10^{6} ; \mathrm{GD}_{1 \%}=84.996 \times 10^{6} ; \mathrm{GD}_{0.1 \%}=136.631 \times 10^{6}$} \\
\hline $\begin{array}{l}\text { Mineral nitrogen } \mathrm{NO}_{3}^{-} \\
\text {assimilating microorganisms }\end{array}$ & $\begin{array}{l}42.874 \times 10^{6} \\
\pm 3274\end{array}$ & $\begin{array}{l}164.815 \times 10^{6} \\
\pm 6419.011\end{array}$ & $\mathrm{t}_{\mathrm{exp} .}=3.378>\mathrm{t}_{\mathrm{tab} .1 .0 \%}$ & $+121.940 \times 10^{6 * *}$ \\
\hline
\end{tabular}


Table.3 Values of structural microbiological indices showing the direction of the mineralization processes in cinnamon pseudopodzolic soil/Planosol/ after introduce of sapropels

\begin{tabular}{|c|c|c|c|c|}
\hline \multirow{2}{*}{$\begin{array}{c}\text { Structural } \\
\text { Microbiological } \\
\text { indices }\end{array}$} & $\begin{array}{c}\text { Planosol - } \\
\text { without sapropels } \\
\text { /control/ }\end{array}$ & $\begin{array}{c}\text { Planosol } \\
+ \\
\text { sapropels } \\
\end{array}$ & $\begin{array}{c}\text { Values of the } \\
\text { criterion of Student } \\
(\mathrm{t})\end{array}$ & \multirow{2}{*}{$\begin{array}{l}\text { Statistical } \\
\text { significance } \\
\text { of the } \\
\text { differences } \\
( \pm D)\end{array}$} \\
\hline & $\begin{array}{c}\text { values } \\
\pm \text { confidence } \\
\text { interval } \\
\overline{\mathrm{x}} \pm_{\Delta} \mathrm{N}_{(\mathrm{p} \leq 0.95}\end{array}$ & $\begin{array}{c}\text { values } \\
\pm \text { confidence } \\
\text { interval } \\
\overline{\mathrm{x}} \pm_{\Delta} \mathrm{N}_{(\mathrm{p} \leq 0.95}\end{array}$ & $\begin{array}{l}\text { significance levels } \\
\mathrm{t}_{\text {tab.5.0\% }}=1.943 \\
\mathrm{t}_{\text {tab.1.0\% }}=3.143 \\
\mathrm{t}_{\text {tab.0.1\% }}=5.208\end{array}$ & \\
\hline Oligotrophic index & $0.618 \pm 0.393$ & $0.440 \pm 0.332$ & $\mathrm{t}_{\mathrm{exp}}=4.060>\mathrm{t}_{\mathrm{tab} .1 .0 \%}$ & $-0.178^{* *}$ \\
\hline \multicolumn{5}{|c|}{$\mathrm{GD}_{5 \%}=0.107 ; \mathrm{GD}_{1 \%}=0.163 ; \mathrm{GD}_{0.1 \%}=0.261$} \\
\hline $\begin{array}{l}\text { Mineralization- } \\
\text { immobilization } \\
\text { index by }\left(\mathrm{NH}_{4}^{+}\right)\end{array}$ & $0.253 \pm 0.251$ & $0.399 \pm 0.316$ & $\mathrm{t}_{\text {exp. }}=1.873<\mathrm{t}_{\text {tab.5.0\% }}$ & $+0.146^{\text {n.d. }}$ \\
\hline \multicolumn{5}{|c|}{$\mathrm{GD}_{5 \%}=0.191 ; \mathrm{GD}_{1 \%}=0.289 ; \mathrm{GD}_{0.1 \%}=0.465$} \\
\hline $\begin{array}{l}\text { Mineralization- } \\
\text { immobilization } \\
\text { index by }\left(\mathrm{NO}_{3}{ }^{-}\right)\end{array}$ & $0.603 \pm 0.388$ & $0.544 \pm 0.184$ & $\mathrm{t}_{\mathrm{exp} .}=0.256<\mathrm{t}_{\mathrm{tab} .5 .0 \%}$ & $-0.059^{\text {n.d. }}$ \\
\hline
\end{tabular}

Fig.1 Relative shares (\%) of trophic groups microorganisms of overall population density in microbial communities

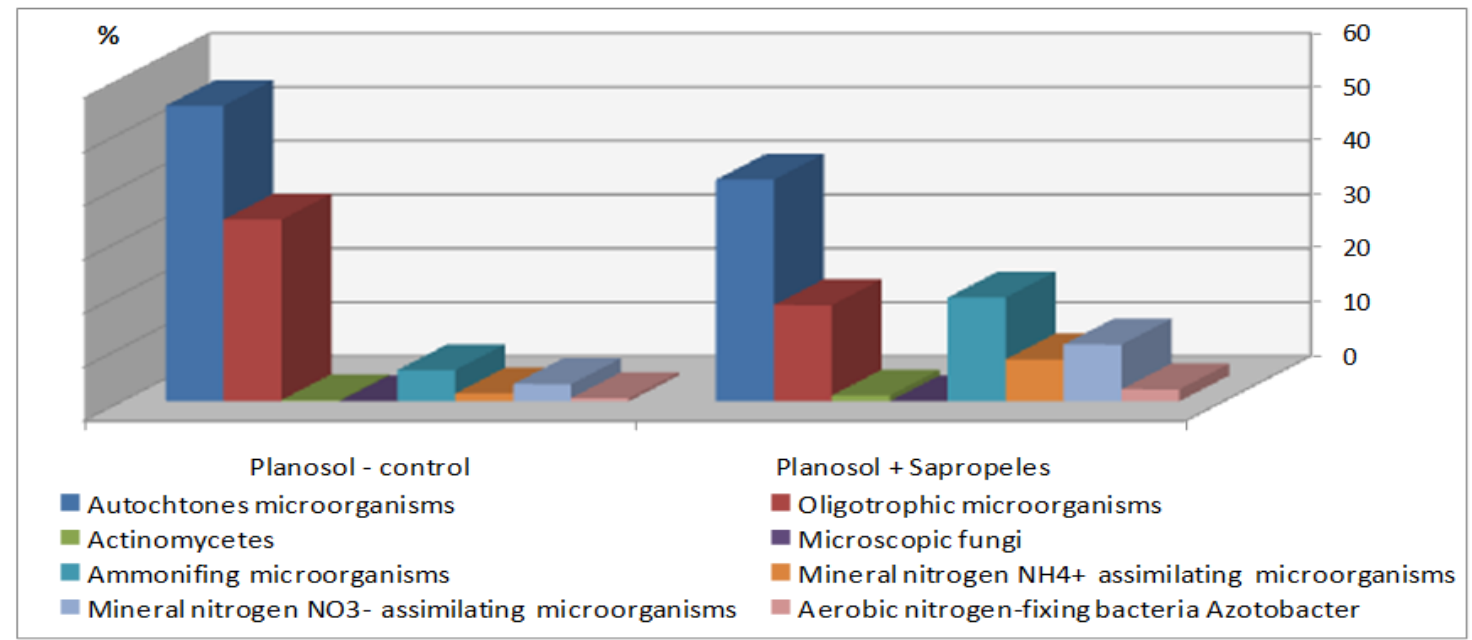

The influence of the sapropels had been $64.33 \%$ and was proven $\left(\mathrm{p} \leq 0.01 ; \mathrm{F}_{\text {exp. }}=12.62>\mathrm{F}_{\text {tab. }} .99 \%\right.$ $=12.25)$. The species is highly sensitive to the conditions of the soil background. The quantity of bacteria is low at low humus content, high acidity and strengthened processes of leaching (Voynova et al., 1983). The presence of sapropels, changes these qualities at cinnamonpseudopodzolicsoil used in the study and create favorable conditions for its development. Strong stimulating effect on population density at the group of ammonifying microorganisms has been recorded. The increase compared to control was $223.95 \times 10^{6}$ 
$/ g$ a. d. s. The force of impact of the factor "sapropel" was $98.95 \%$, statistically significant $\left(\mathrm{p} \leq 0.01 ; \quad \mathrm{F}_{\text {exp. }}=662.47>\mathrm{F}_{\text {tab.99\% }}=12.25\right) . \quad$ The trophic group of ammonifing microorganisms is numerous and diverse by composition that are engaged to the mineralization of nitrogencontaining organic compounds. An increase in the quantities of both groups of mineral nitrogen assimilating microorganisms under the influence of sapropels was observed. An increase at the group of bacteria using $\mathrm{NH}_{4}{ }^{+}-\mathrm{N}$ for their construction needs was more than six times compared to control $-102.28 \times 10^{6} / \mathrm{g}$ a. d. s. The impact has $68.86 \%$ effective, proven at high confidence level $\left(\mathrm{p} \leq 0.01 ; \mathrm{F}_{\text {exp. }}=15.48>\mathrm{F}\right.$ tab.99\% = 12.25). The density of bacteria assimilating $\mathrm{NO}^{-}-\mathrm{N}$ was increased around four times - with $121.94 \times 10^{6} / \mathrm{g}$ a. d. s. The changes were reliable, the impact of the factor was $55.90 \%$, at $\mathrm{p} \leq 0.01 \quad$ ( $\mathrm{F}_{\text {exp. }}=8.87>\mathrm{F}_{\text {tab. }} .95 \%$ $=5.59)$. Stimulation effect on the density in these groups of microorganisms is probably due to the composition of the organic matter in sapropels. According to Velev et al., (1992) it has a multiple character and is genetically heterogeneous. It is characterized by an increased content of slightly-hydrolysable substances (from 12.7 to $31.7 \%$ ), bitumoides (2.3 to $3 \%$ ), humic acids and a relatively high content of insoluble organic matter (56.3 to $58.1 \%)$. The ratio between the number of ammonifying and mineral nitrogen assimilating microorganisms in the microbial community was not disturbed (Table 3). Index values indicate active processes of mineralization, i.e. increase of nitrogen $\left(\mathrm{NH}_{4}{ }^{+}\right.$and $\left.\mathrm{NO}_{3}{ }^{-}\right)$ions absorbed by plants.

Population density in the microbial community as a whole has increased by $16.47 \%$ under the influence of sapropels. The relative shares of different trophic groups microorganisms in community were changed (Fig. 1). The highest share in the soil without sapropels (control) occupied of autochthonous (54.96\%) and oligotrophic microorganisms (33.78\%).The other trophic groups had low percentage participation: ammonifying microorganisms had
$5.80 \%$; mineral nitrogen assimilating microorganisms had 4.63\%; nitrogen-fixing aerobic bacteria $A$. chroococcum had $0.59 \%$ andactinomycetes had $0.23 \%$.

The shares of these groups of microorganisms in microbial communities formed after introducing to sapropels greatly were increased: ammonifying microorganisms - 19.30\%; mineral nitrogen assimilating microorganisms $18.34 \%$; A. chroococcum - $2.21 \%$ and actinomycetes $-1.07 \%$.

In conclusion received results show positive changes at the microflora in cinnamon pseudopodzolic soil (Planosol), respectively its biological properties, under influence the sapropels. Strong stimulating effect on the quantitative development at groups of microorganisms linked with main transformations of nitrogen compounds in the soil have been established. Processes of mineralization are dominating the degree of oligotrophic was low and suggesting accumulation to nutrients assimilable by plants and to increase the humus content. Black Sea deep-water sediments may be used successfully to improve the properties of the cinnamon pseudopodzolic soil (Planosol), nitrogen balance and nutrient regime of soil.

\section{References}

Alexander, M. 1991. Introduction to soil microbiology. Krieger Publ. Co., Malabar, Florida: 467

Atlas, R. and Bartha, R. 1981. Microbial ecology: fundamentals and applications. Addison-Wesley Publ. Co. Ins: 560

Barrios, E. 2007. Soil biota, ecosystem services and land productivity. Ecol. Economics, 64: $269-285$

Baksiene, E. 2009. The influence of lake sediments on the fertility of Cambisol. Agron. Res., 7: 175-182

Bozhinova, R., N. Nikolov, Ts. Hristeva. 2015. Influence of deep organogenic-mineral sediments (sapropels) on accumulation of $\mathrm{Pb}, \mathrm{Cd}, \mathrm{Zn}$ and $\mathrm{Cu}$ in tobacco grown on 
acidic soil (Planosol). Scientific J. Ecol. Future, 1-2: 39-43.

Bozukov, H. and J. Kochev. 2014. Experience with Black Sea sapropel at growing tobacco seedlings in "float system". $J$. Geol. Mineral resources of the oceans, 3: 44-48

Brussaard, L., P.C. de Ruiter, G.G. Brown. 2007. Soil biodiversity for agricultural sustainability. Agri. Ecosystems and Environ., 121: 233-244.

Buyer, J.S., J.R. Teasdale, D.P. Roberts, I.A. Zasada, J.E. Maul. 2010. Factors affecting soil microbial community structure in tomato cropping systems. Soil Biol. Biochem., 42: 831-841.

Coolen M., H. Cypionka, A. Sass, H. Sass, J. Overmann. 2002. Ongoing modification of Mediterranean Pleistocene sapropels mediated by prokaryotes. Sci., 296: 24072410

Dimitrov, I. and V. Sabev. 2005. Application possibilities of Black Sea sapropels to stimulate the development of NitrogenFixing tuberous bacteria in legume crops. Proc. of the VII th Scientific-Practical Conference "Ecological problems of agriculture", Plovdiv, Bulgaria vol. L, 1: 129-140.

Domsh, K.H., G. Jagnow, T.H. Anderson. 1983. Residue Rev., 86: 65-105.

Doran, J.W. and M.R. Zeiss. 2000. Soil health and sustainability: managing the biotic component of soil quality. Appl. Soil Ecol., 15: 3-11

Dobrovolskaya, T.G., D.G. Zvyagintsev, I.Y. Chernov, A.V. Golovchenko, G.M. Zenova, L.V. Lysak, N.A. Manucharova, O.E. Marfenina, L.M. Polyanskaya, A.L. Stepanov, M.M. Umarov. 2015. The role of microorganisms in the ecological functions of soils. J. Eurasian Soil Sci., vol. 48, 9: 959 - 967

Dobrovolskaya, T.G., K.A. Khusnetdinova, N.A. Manucharova, P.N. Balabko. 2016. The structure and functions of bacterial communities in an agrocenosis. $J$. Eurasian Soil Sci., vol. 49, 1: 70 - 79.

Dzyuban, A.N. 2002. Intensity of the microbiological processes of the methane cycle in different types of Baltic lakes. Microbiol., 71: 98-104.

Emeis, K.C. and H. Weissert. 2009. TethyanMediterranean organic carbon-rich sediments from Mesozoic black shales to sapropels. Sedimentol., 56: 247-266.

Fritz, J.I., I.H. Franke-Whittle, S. Haindl, H. Insam, R. Braun. 2012. Microbiological community analysis of vermicompost tea and its influence on the growth of vegetables and cereals. Canadian $J$. Microbiol., 58: 836-847

Grantina-Levina, L., A. Uarlsons, U. Andersone-Ozola, G. Levinsh. 2014. Effect of freshwater sapropel on plants in respect to its growth affecting activity and cultivable microorganism content. Zemdirbyste-Agri., vol. 101, No. 4: 355-366.

Grudeva, C., P. Moncheva, S. Naumova, B. Gocheva, T. Nedeva, Antonova-Nikolova S. 2006. Manual of Microbiology. Univ. Ed. "St. Kliment Ohridski ", Sofia, Bulgaria: 146-151

Ishida, Y. and H. Kadota. 1981. Growth patterns and substrate requirements of naturally occurring obligate oligotrophs. Microb. Ecol., 7: 123-130

Lucas, S.T. 2013. Managing soil microbial communities with organic amendments to promote soil aggregate formation and plant health. Theses and Dissertations. Plant and Soil Sciences. University of Kentucky Knowledge.

Kennedy, A.C., T.L. Stubbs, W.F. Schillinger. 2004. Soil and crop management effects on soil microbiology. In: Magdoff, F., Weil, R.R. (eds.) Soil organic matter in sustainable agriculture. CRC Press. Boca Raton, FL: 295-326.

Lal, R. 2009. Soils and sustainable agriculture: A review. In: Lichtfouse, E., Navarrete, M., Debaeke, P., Veronique, S., Alberola, C. (eds.) Sustainable Agriculture. Springer, Netherlands: 15-23.

Larkin, R.P., C. W. Honeycutt, T. S. Griffin. 2006. Effect of swine and dairy manure amendments on microbial communities in 
three soils as influenced by environmental conditions. Biol. Fertility of Soils, 43: 5161.

Nikolov, N. 2011. Application of Black Sea sapropels for improving of rooting and growth of Kazanlika oil-bearing rose clippings, Stiinta Agricola, Chisinau. 1: 36.

Nikolov, N. and N. Shaban. 2011. Application of Black Sea sapropelles as amendment by growing of vegetable crop seedlings. Bulg. J. Agric. Sci., 17: 167-172

Nikolov, N. 2014. Application of deep water Black Sea sediments (Sapropels) for neutralization of soil acidity at different types of acidic soils, J. Int. Scient. Publications, vol.8: 454-460

Nikolov N. and V. Tringovska. 2014. Neutralization of peat for substrates preparation, using Black Sea Organomineral Sediments (Sapropels). Turkish J. Agri. Natural Sci., Special Issue: 1: 603607.

Plohinsky, N. 1980. Biometrics algorithms. Ed. Moscow University, Moscow: 150-184.

Saison, C., V. Degrange, R. Oliver, P. Millard, C. Commeaux, D. Montange, X. Le Roux. 2006. Alteration and resilience of the soil microbial community following compost amendment: effects of compost level and compost-borne microbial community. Environ. Microbiol., 8: 247257.

Schutter, M.E. and R.P. Dick. 2001. Shifts in substrate utilization potential and structure of soil microbial communities in response to carbon substrates. Soil Biol. Biochem., 33: 1481-1491.

Shnyukov, E.F., P.S. Dimitrov, D.P. Dimitrov, A.P. Ziborov, T.S. Cookovskaja. 2009.
Unconventional resources from the bottom of the Black Sea and the possibility of their use as a raw material complex. Proc. of the Xth Conference of the Open and Underwater Mining of Minerals. June 07-11, Varna, Bulgaria: 48-54.

Sparling, G. 1997. Soil microbial biomass, activity, and nutrient cycling as indicators of soil health. In: Pankhurst, C., Doube, B.M., Gupta, V.V.S.R. (eds.) Biological indicators of soil health. CAB International, Wallingford, United Kingdom: 97-119.

Süss, J., B. Engelen, H. Cypionka, H. Sass. 2004. Quantitative analysis of bacterial communities from Mediterranean sapropels based on cultivation-dependent methods. FEMS Microbiol. Ecol., 51(1): 109-121.

Terziev, Z., H. Kirchev, N. Semkova. 2007. Results of potato field production using new granule fertilizers and amelioration containing sea sapropels. Res. J. Agri. Sci., 39: 93-98

Velev, C., P. Dimitrov, M. Fire. 1992. Structure and composition of the Holocene sapropeloidi the western part of the Black Sea. Sci. researches Institute of Oceanology BAS, Varna, vol. 1: 53-64

Voynova, G., B. Rankov, G. Ampova. 1983. Microorganisms and Fertility. Ed “Zemizdat", Sofia, Bulgaria: 28 -139.

Wurzbacher, C.M., F. Bärlocher, H.P. Grossart. 2010. Fungi in lake ecosystems. Aquatic Microbiol. Ecol., 59: 125-149

Zenova, G.M., N.V. Mikhailova, D.G. Zvyagintsev. 2001. Ecology of soil oligosporous actinomycetes. J. Eurasian Soil Sci., Vol. 34(7): 765-773.

\section{How to cite this article:}

Tsveta H. Hristeva and Radka P. Bozhinova. 2017. Microbiological Characteristic of Cinnamon Pseudopodzolic Soil (Planosol) at Using of Black Sea Deep-Water Sediments (Sapropels). Int.J.Curr.Microbiol.App.Sci. 6(4): 125-133.doi: https://doi.org/10.20546/ijcmas.2017.604.015 